\title{
Effect of Dietary Fat and Vitamin E on $\alpha$-Tocopherol in Milk from Dairy Cows ${ }^{1}$
}

\author{
W. P. Weiss and D. J. Wyatt \\ Department of Animal Sciences, \\ Ohio Agricultural Research and Development Center, \\ The Ohio State University, Wooster 44691
}

\section{ABSTRACT}

Diets with different fat treatments and with 25,125 , or $250 \mathrm{IU}$ of supplemental vitamin E (all-rac $\alpha$-tocopheryl acetate)/kg of dry matter (DM) were fed for 28 $\mathrm{d}$ to midlactation Holstein cows to determine factors affecting concentrations of $\alpha$-tocopherol in milk. Diets contained no supplemental fat or $2.25 \%$ added fat from roasted soybeans or tallow. Vitamin E treatment had no effects on production, but fat supplementation increased milk yield (37.2 vs. $35.1 \mathrm{~kg} / \mathrm{d}$ ). Cows fed RSB ate more DM (24.0 vs. $21.9 \mathrm{~kg} / \mathrm{d})$ and produced more milk fat than cows fed tallow. Supplemental fat increased plasma concentrations of $\alpha$-tocopherol and cholesterol. Increased intake of $\alpha$-tocopherol linearly increased concentrations of $\alpha$-tocopherol in plasma but the rate of increase was 1.9 times greater when fat was fed. Plasma $\alpha$-tocopherol concentrations were linearly related to concentrations in milk, but a change in plasma $\alpha$-tocopherol resulted in a smaller change in milk $\alpha$-tocopherol when fat was fed than when it was not. Fat treatment did not affect plasma $\alpha$-tocopherol expressed relative to plasma cholesterol ( $\mathrm{mg} \alpha$-tocopherol/g cholesterol) or relationships between plasma $\alpha$ tocopherol/g of cholesterol and milk $\alpha$-tocopherol. These data suggest that concentrations of $\alpha$-tocopherol in milk are a function of the $\alpha$-tocopherol enrichment of the plasma lipid fraction and enrichment of that fraction is saturable.

(Key words: vitamin E, tallow, roasted soybeans, trans-fatty acids)

Abbreviation key: PUFA = polyunsaturated fatty acids, $\mathbf{R S B}=$ roasted soybeans.

\section{INTRODUCTION}

Increasing the concentration of $\alpha$-tocopherol in milk can improve the oxidative stability of milk (Charmley

\footnotetext{
Received April 23, 2003.

Accepted June 10, 2003.

Corresponding author: W. P. Weiss; e-mail: weiss.6@osu.edu.

${ }^{1}$ Salaries and research support provided by state and federal funds appropriated to the Ohio Agricultural Research and Development Center, The Ohio State University. Manuscript 11-03AS.
}

et al., 1993; Charmley and Nicholson, 1994; Focant et al., 1998) and would increase $\alpha$-tocopherol intake by people consuming dairy products. Currently, the median daily intake of $\alpha$-tocopherol by Americans is less than its recommended daily allowance (Food and $\mathrm{Nu}-$ trition Board, 2000). Increased intake of $\alpha$-tocopherol by cows increases the $\alpha$-tocopherol content of milk (Goering et al., 1976; Atwal et al., 1990; St-Laurent et al., 1990; Atwal et al., 1991; Charmley et al., 1993; Charmley and Nicholson, 1994). In most of those studies, only two amounts of vitamin $\mathrm{E}$ (from all-rac $\alpha$ tocopheryl acetate) were fed (usually a control with little or no supplemental vitamin $\mathrm{E}$ and a treatment diet that provided several grams of supplemental vitamin E). Although these studies showed clearly that vitamin $\mathrm{E}$ supplementation increased $\alpha$-tocopherol in milk, they are less useful in quantifying relationships between vitamin $\mathrm{E}$ intake, milk $\alpha$-tocopherol concentrations, and plasma $\alpha$-tocopherol concentrations.

Feeding certain sources of unsaturated fatty acids increases the risk for developing oxidized flavor in milk by changing its fatty acid composition (Goering et al., 1976; Charmley and Nicholson, 1994; Focant et al., 1998; Timmons et al., 2001). Dietary fat supplementation has generally not affected $\alpha$-tocopherol concentrations in milk (Atwal et al., 1990; Atwal et al., 1991; Charmley and Nicholson, 1994), but increased milk $\alpha$ tocopherol has been reported when oilseeds were fed (Focant et al. 1998; Morales et al., 2000). The primary objective of this experiment was to quantify the effects of supplemental dietary fats on the transfer of dietary $\alpha$-tocopherol to milk and on the relationship between $\alpha$-tocopherol in plasma and milk.

\section{MATERIALS AND METHODS}

\section{Cows and Treatments}

Fifty-four Holstein cows (160 \pm 11 DIM) were allotted to 6 blocks based on calving date and lactation number ( 3 blocks of primiparious cows) and fed one of nine diets. Treatments were in a $3 \times 3$ factorial arrangement and contained either no supplemental fat or $2.25 \%$ added fat (\% of DM) from tallow or whole 
Table 1. Composition of the diets (\% of DM).

\begin{tabular}{lccr}
\hline & Control & Tallow & RSB \\
\hline Corn silage & 37.80 & 37.80 & 37.80 \\
Alfalfa hay & 7.70 & 7.70 & 7.70 \\
Alfalfa silage & 7.20 & 7.20 & 7.20 \\
Tallow & $\ldots$ & 2.35 & $\ldots$ \\
Roasted soybeans, whole & $\ldots$ & $\ldots$ & 12.30 \\
Ground corn & 15.76 & 12.75 & 14.55 \\
Soybean meal, 44\% CP & 14.56 & 14.94 & 6.00 \\
Soybean hulls & 9.72 & 9.90 & 8.60 \\
Soypass & 1.62 & 1.62 & 0.78 \\
Limestone & 0.57 & 0.67 & 0.66 \\
Sodium bicarbonate & 0.66 & 0.66 & 0.32 \\
Dicalcium phosphate & 0.32 & 0.32 & 0.16 \\
Magnesium oxide & 0.16 & 0.16 & 0.43 \\
Trace mineral/vitamin premix & & 3.50 \\
Vitamin E supplement & & 0.43 & \\
Nutrients & 0.43 & 3.50 & 17.8 \\
CP & 3.50 & & 33.1 \\
NDF & & 16.9 & 5.5 \\
Long-chain fatty acids & 17.1 & 32.8 & 5.4 \\
\hline
\end{tabular}

${ }^{1}$ Lignotech USA, Rothschild, WI.

${ }^{2}$ Premix contained $62.71 \%$ trace mineralized salt, $34.21 \%$ sodium selenate ( $200 \mathrm{mg}$ of Se/kg), $2.28 \%$ Zinpro 100 (Eden Prairie, MN), 0.46\% $\mathrm{ZnO}, 0.34 \% \mathrm{Cu}_{2} \mathrm{SO}_{4}, 872 \mathrm{IU}$ of vitamin $\mathrm{A} / \mathrm{g}$, and $262 \mathrm{IU}$ of vitamin D/g.

${ }^{3}$ The 25, 125 and 250 IU supplements contained 98.86, 94.32, and 88.64\% ground corn and 1.14, 5.68, and $11.36 \%$ vitamin E supplement (44 IU/g from all-rac $\alpha$-tocopheryl acetate), respectively.

roasted soybeans (RSB) and 25, 125, or 250 IU of supplemental vitamin $\mathrm{E} / \mathrm{kg}$ of DM from all-rac $\alpha$-tocopheryl acetate (Table 1). The tallow and vitamin E were incorporated into the concentrate mixes at the feed mill and RSB were mixed into the TMR at the barn. Treatment diets were fed for $28 \mathrm{~d}$. Previous research has shown that concentrations of $\alpha$-tocopherol in plasma and milk reach steady-state within $1 \mathrm{wk}$ of vitamin E supplementation (St-Laurent et al., 1990). All diets were formulated to meet or exceed NRC (1989) requirements for minerals and vitamins A and D. Cows were housed in tiestalls and fed a TMR once daily in amounts to ensure at least 5\% orts. Daily DMI and milk production (milked twice daily) were recorded. Cows were weighed at that start and end of the experiment.

\section{Sampling and Analytical Procedures}

Forages, concentrates, and RSB were sampled weekly and composited by feeding period (blocks 1 and 2 were fed concurrently, as were blocks 3 and 4 , and blocks 5 and 6) for a total of 3 samples per feed. Weekly silage samples were analyzed for $\mathrm{DM}\left(100^{\circ} \mathrm{C}\right.$ for 24 hr) to adjust TMR for changes in moisture content. Milk (a.m. and p.m.) was sampled on d 0, 14, and 28. The a.m. and p.m. samples were composited by weight into a single sample for each cow-day. Blood was collected from the tail vein into vacuum tubes containing sodium heparin $6 \mathrm{~h}$ after the a.m. milk sample was taken (6 h before the p.m. milk sample) on $\mathrm{d} 0,14$, and 28.

Feeds were analyzed for CP (AOAC, 1990), NDF following Procedure A (Van Soest et al., 1991) except that an ANKOM 200 Fiber Analyzer (ANKOM Technology, Fairport, NY) was used, $\alpha$-tocopherol using HPLC following saponification (Indyk, 1988), and long chain fatty acids. Long-chain fatty acids were assayed following the procedure of Sukhija and Palmquist (1988) except that $10 \%$ methanolic $\mathrm{HCl}$ was used rather than $5 \%$, and $10 \mathrm{ml}$ of $6 \% \mathrm{~K}_{2} \mathrm{CO}_{3}$ was used rather than $5 \mathrm{ml}$. Plasma was separated by centrifugation $\left(10,000 \times g\right.$ for $15 \mathrm{~min}$ at $\left.4^{\circ} \mathrm{C}\right)$ and stored frozen $\left(-20^{\circ} \mathrm{C}\right)$ until analyzed for $\alpha$-tocopherol via HPLC (Hogan et al., 1990) and cholesterol (SIGMA, 1999). $\alpha$ Tocopherol was extracted from the composited (a.m. and p.m.) milk samples (Indyk, 1988) and quantified using HPLC (Hogan et al., 1990). Milk fatty acids were methylated using a two-step procedure (Kramer et al., 1997), and quantified by GLC. A subsample of the milk was sent to Ohio DHI Cooperative (Powell $\mathrm{OH}$ ) and analyzed for fat and true protein per approved procedures (AOAC, 1990) with a B2000 Infrared Analyzer (Bentley Instruments, Chaska MN). Yields of true protein, fat, and $\alpha$-tocopherol were calculated by multiplying the concentrations of those fractions by yield of milk obtained the day the samples were collected.

\section{Statistical Analysis}

Yields of milk, milk protein, and milk fat, change in $\mathrm{BW}$, and DMI were averaged within cow over the 28 
Table 2. Concentrations of $\alpha$-tocopherol in feeds (DM basis) and diets. Standard deviation is in parenthesis $(\mathrm{N}=3)$.

\begin{tabular}{lc}
\hline Ingredient & $\alpha$-tocopherol, $\mathrm{mg} / \mathrm{kg}$ \\
\hline Corn silage & $14.4(5.1)$ \\
Alfalfa hay & $28.3(10.8)$ \\
Alfalfa silage & $47.8(15.2)$ \\
Roasted soybeans (RSB) & $14.2(3.7)$ \\
Control concentrate & $9.2(0.8)$ \\
Tallow concentrate & $8.2(2.1)$ \\
RSB concentrate & $7.5(1.0)$ \\
25 IU/kg supplement & $607(35)$ \\
125 IU/kg supplement & $2779(47)$ \\
250 IU/kg supplement & $5828(7)$ \\
25 IU/kg diets ${ }^{1}$ & 36 \\
125 IU/kg diets & 112 \\
250 IU/kg diets & \\
\hline
\end{tabular}

${ }^{1}$ The tocopherol concentrations for the diets were calculated from tocopherol concentrations of the ingredients. The concentration of $\alpha$ tocopherol in the Control, Tallow and RSB diets were the same within a vitamin $\mathrm{E}$ treatment.

$\mathrm{d}$ period and analyzed statistically using Proc MIXED (SAS, 1999). The model included block (random, $5 \mathrm{df}$ ), fat treatment (fixed, $2 \mathrm{df}$ ), vitamin $\mathrm{E}$ treatment (fixed, $2 \mathrm{df}$ ), fat $\times$ vitamin $\mathrm{E}$ interaction ( $4 \mathrm{df}$ ), and error (40 df). Blood and milk measures from d 14 and 28 were analyzed using Proc MIXED (SAS, 1999). The model included block (random, $5 \mathrm{df}$ ), fat treatment (fixed, 2 df), vitamin $E$ treatment (fixed, $2 \mathrm{df}$ ), fat $\times$ vitamin $\mathrm{E}$ interaction ( $4 \mathrm{df}$ ), day (fixed, repeated measure, $1 \mathrm{df}$ ), day $\times$ fat $(2 \mathrm{df})$, day $\times$ vitamin $E(2 \mathrm{df})$, day $\times$ fat $\times$ vitamin $\mathrm{E}$ (4 df), and error (85 df). Based on Akaike's information criteria (SAS, 1999), compound symmetry was the most appropriate covariance structure. The fat main effect was partitioned into two contrasts (control vs. fat-supplemented and tallow vs. RSB). The vitamin $\mathrm{E}$ main effect was partitioned into linear and quadratic contrasts (adjusted for unequal spacing of treatments). The fat $\times$ vitamin $\mathrm{E}$ interaction was partitioned into linear vitamin $\mathrm{E} \times$ fat supplementation (no fat vs. fat-supplemented), linear vitamin $\mathrm{E} \times$ fat type (RSB vs. tallow), quadratic vitamin $\mathrm{E} \times$ fat supplementation, and quadratic vitamin $\mathrm{E} \times$ fat type.

The relationships between $\alpha$-tocopherol intake $(\mathrm{mg} /$ d) and plasma and milk $\alpha$-tocopherol concentrations and secretion of $\alpha$-tocopherol via milk were quantified using Proc MIXED (SAS, 1999). The initial model included block (random, $5 \mathrm{df}$ ), fat treatment (fixed, $1 \mathrm{df}$ ), vitamin $\mathrm{E}$ intake (continuous, $1 \mathrm{df}$ ), vitamin $\mathrm{E}$ intake ${ }^{2}$ $(1 \mathrm{df})$, fat $\times$ vitamin $\mathrm{E}$ intake $(1 \mathrm{df})$ fat $\times$ vitamin $\mathrm{E}$ intake $^{2}(1 \mathrm{df})$ and error (43 df). Variables that were not significant $(P>0.10)$ were removed from the model. Daily intake of $\alpha$-tocopherol was calculated by multiplying $28 \mathrm{~d}$ average DMI for each cow by average concentration of $\alpha$-tocopherol of the cow's respective diet (Table 2). For these analyses plasma and milk $\alpha$-to- copherol values on d 14 and d 28 were averaged within cow. Relationships between concentrations of $\alpha$-tocopherol in plasma and concentration and daily secretion of $\alpha$-tocopherol in milk were quantified using Proc MIXED with similar models except that day and day interactions were included initially. These terms were not significant for any dependent variable and were removed from the final models.

\section{RESULTS AND DISCUSSION}

\section{Production Measures}

The 25, 125, and $250 \mathrm{IU} / \mathrm{kg}$ diets contained 36, 112, and $219 \mathrm{mg}$ of total $\alpha$-tocopherol $/ \mathrm{kg}$ of DM. Those values include supplemental $\alpha$-tocopherol (from all-rac $\alpha$-tocopheryl acetate) and the $\alpha$-tocopherol naturally found in feeds ( $R R R$ - $\alpha$-tocopherol). Assuming the vitamin E supplement (fed at $3.5 \%$ of diet DM) contained about $8 \mathrm{mg} R R R$ - $\alpha$-tocopherol/kg (the same as the main concentrate mixes), all diets contained about 15 $\mathrm{mg} R R R$ - $\alpha$-tocopherol/kg diet DM and 21, 97, and 204 $\mathrm{mg} \alpha$-tocopherol from all-rac $\alpha$-tocopheryl acetate/kg $\mathrm{DM}$ for the 25, 125, and 250 IU diets. Based on these calculations, mean intakes of supplemental $\alpha$-tocopherol (averaged across fat sources) were 480, 2190, and $4590 \mathrm{IU} / \mathrm{d}$. Intake of total $\alpha$-tocopherol increased linearly $(P<0.001)$ with vitamin E treatment (Table 3$)$ and was greater $(P<0.01)$ for cows fed RSB than for those fed tallow (2910 vs. $2580 \mathrm{mg} / \mathrm{d})$ because of differences in DMI.

Vitamin $\mathrm{E}$ and the vitamin $\mathrm{E}$ by fat interaction had no effect on DMI, milk yield, and yields and concentrations of milk fat and protein (Table 3). Dry matter intake for cows fed supplemental fat (RSB or tallow) was not different from cows fed diets without supplemental fat, but cows fed RSB had higher DMI $(P<$ $0.01)$ than cows fed tallow (24.0 vs. $21.8 \mathrm{~kg} / \mathrm{d})$. Milk yields were higher $(P<0.06)$ for cows fed fat than for cows not fed supplemental fat (37.2 vs. $35.1 \mathrm{~kg} / \mathrm{d})$. Milk yield did not differ between cows fed RSB and those fed tallow, but cows fed RSB tended $(P<0.10)$ to produce more energy-corrected milk than cows fed tallow $(38.1 \mathrm{vs} .35 .9 \mathrm{~kg} / \mathrm{d})$. Milk fat percentage was higher $(P$ $<0.04$ ) for cows not fed fat than for those fed supplemental fat because of the low milk fat percentage for cows fed tallow. Yield of milk fat was not different between cows fed fat and those not fed fat but was higher $(P<0.01)$ for cows fed RSB than for those fed tallow. Milk protein yield and concentration were not different among treatments. Cows fed RSB gained more BW $(P<0.05)$ than cows fed tallow. 
Table 3. Effect of dietary fat and supplemental vitamin E (25, 125, or $250 \mathrm{IU} / \mathrm{kg} \mathrm{DM})$ on production measures.

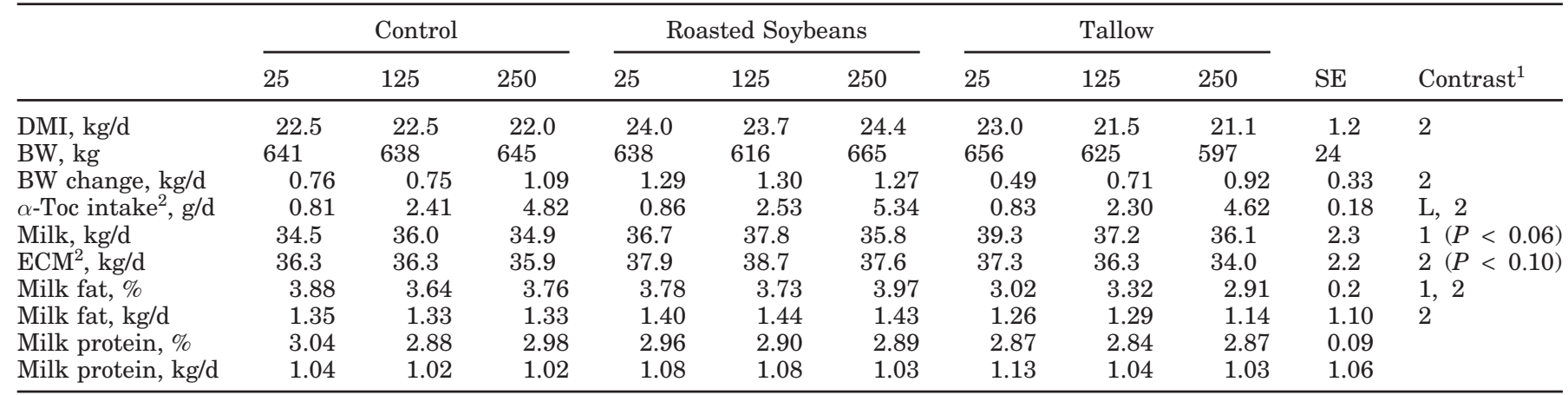

${ }^{1}$ Contrasts $(P<0.05$ unless stated in table): $\mathrm{L}=$ linear effect of vitamin $\mathrm{E}$ treatment; 1 = fat-supplemented vs. control; $2=$ roasted soybeans vs. tallow.

${ }^{2} \alpha$-Toc $=\alpha$-tocopherol; ECM = energy-corrected milk (Tyrrell and Reid, 1965).

\section{Milk Fatty Acids}

Cows fed diets with supplemental fat had higher $(P$ $<0.01$ ) concentrations (\% of total milk fatty acids) of all milk fatty acids with $>16 \mathrm{C}$ and lower $(P<0.01)$ concentrations of fatty acids with $\leq 16 \mathrm{C}$ than cows fed the control diet (Table 4). Cows fed RSB had higher $(P<0.01)$ concentrations of fatty acids with $<16 \mathrm{C}, \mathrm{C}$ 18, trans-11 C 18:1, C 18:2 and C18:3 and lower $(P<$ 0.01 ) concentrations of C 16, cis-9 C18:1, cis-11 C 18:1, trans-10 C 18:1 and cis-9, trans-11 conjugated linoleic acid (CLA) than cows fed tallow. Cows fed tallow had substantially higher concentrations of CLA than cows fed the other diets. Morales et al. (2000) reported higher CLA concentrations when Holstein cows were fed RSB compared with cows fed tallow. Onetti et al. (2001) reported only small differences in CLA concen- trations of milk from cows fed tallow compared with cows fed no supplemental fat.

No effects of vitamin $E$ treatment or vitamin $E \times$ fat interactions were observed for any milk fatty acids except for a fat source by quadratic vitamin $\mathrm{E}$ interaction for CLA $(P<0.01)$ and a fat amount by linear vitamin E interaction for trans-10 C 18:1 $(P<0.05)$. The interaction observed for trans-10 C 18:1 was probably caused by one cow that had extremely high trans$10 \mathrm{C} \mathrm{18:1} \mathrm{(5.1 \%} \mathrm{of} \mathrm{total} \mathrm{fatty} \mathrm{acids)} \mathrm{and} \mathrm{was} \mathrm{fed} \mathrm{the}$ control diet with $25 \mathrm{IU} / \mathrm{kg}$ of vitamin $\mathrm{E}$. When that cow was excluded the interaction became nonsignificant $(P$ $>0.33$ ). The concentration of CLA tended to decrease with increasing vitamin $\mathrm{E}$ when no supplemental fat or tallow was fed, but when RSB was fed the concentration was highest when the intermediate vitamin $\mathrm{E}$

Table 4. Effect of dietary fat and supplemental vitamin E (25, 125, or $250 \mathrm{IU} / \mathrm{kg}$ DM) on fatty acid composition of milk fat $(\mathrm{g} / 100 \mathrm{~g} \text { of total fatty acids })^{1}$.

\begin{tabular}{|c|c|c|c|c|c|c|c|c|c|c|}
\hline \multirow[b]{2}{*}{ Fatty acid ${ }^{2}$} & \multicolumn{3}{|c|}{ Control } & \multicolumn{3}{|c|}{ Roasted Soybeans } & \multicolumn{3}{|c|}{ Tallow } & \multirow[b]{2}{*}{$\mathrm{SE}$} \\
\hline & 25 & 125 & 250 & 25 & 125 & 250 & 25 & 125 & 250 & \\
\hline$<16 \mathrm{C}$ & 31.12 & 28.48 & 30.80 & 27.51 & 28.20 & 25.96 & 25.15 & 23.50 & 23.54 & 0.89 \\
\hline $16: 0$ & 33.21 & 36.67 & 35.00 & 28.52 & 28.23 & 28.02 & 29.18 & 30.03 & 30.12 & 0.94 \\
\hline $18: 0$ & 8.24 & 8.76 & 7.87 & 12.24 & 10.45 & 13.03 & 9.34 & 10.40 & 9.50 & 0.51 \\
\hline cis-9 18:1 & 17.63 & 17.95 & 17.80 & 20.68 & 21.04 & 21.51 & 24.00 & 24.10 & 24.04 & 0.81 \\
\hline cis-11 18:1 & 0.68 & 0.58 & 0.58 & 0.57 & 0.64 & 0.54 & 0.76 & 0.69 & 0.89 & 0.06 \\
\hline trans-10 18:1 & 1.28 & 0.39 & 0.49 & 0.48 & 0.63 & 0.56 & 2.40 & 2.46 & 3.28 & 0.35 \\
\hline trans-11 18:1 & 0.68 & 0.81 & 0.77 & 1.24 & 1.53 & 1.36 & 0.92 & 0.92 & 0.52 & 0.14 \\
\hline $18: 2$ & 2.87 & 2.42 & 2.73 & 4.45 & 4.65 & 4.55 & 2.61 & 2.45 & 2.22 & 0.19 \\
\hline $18: 3$ & 0.56 & 0.47 & 0.54 & 0.94 & 0.92 & 0.92 & 0.53 & 0.45 & 0.47 & 0.05 \\
\hline CLA & 0.54 & 0.49 & 0.47 & 0.59 & 0.84 & 0.62 & 0.92 & 0.80 & 0.75 & 0.06 \\
\hline
\end{tabular}

\footnotetext{
${ }^{1}$ For all fatty acids, cows fed fat differed from cows not fed fat $(P<0.01)$ and cows fed tallow differed from cows fed roasted soybeans $(P<0.01)$. No main effects for vitamin $\mathrm{E}$ were observed but a linear vitamin $\mathrm{E} \times$ fat supplementation interaction was observed for trans-10 18:1 $(P<0.05)$ and a quadratic vitamin $\mathrm{E} \times$ fat source interaction was observed for CLA $(P<0.01)$. Values do not sum to 100 because some fatty acids are not shown.

${ }^{2}$ Number of carbons:number of double bonds. CLA = conjugated linoleic acid (cis-9, trans-11 was the only isomer detected).
} 
treatment. The biological meaning of that interaction is unclear. Relationships between milk fatty acids and milk fat are discussed in another paper (Weiss et al., 2003).

\section{Plasma Cholesterol}

Cows fed supplemental fat had higher $(P<0.01)$ plasma cholesterol than cows not fed fat $(249.0$ vs. $180.7 \mathrm{mg} / \mathrm{dl})$ and cows fed tallow had higher $(P<0.04)$ cholesterol than cows fed RSB (Table 5). Feeding supplemental fat consistently elevates plasma cholesterol concentrations (Grummer and Carroll, 1991). The higher plasma cholesterol for cows fed tallow compared with those fed RSB may have been caused by increased consumption of cholesterol or by differences in the profile of absorbed fatty acids. The vitamin $\mathrm{E}$ main effect was not significant, but interactions between fat and vitamin $\mathrm{E}$ treatments were observed. For cows not fed fat, increasing dietary vitamin E decreased plasma cholesterol linearly, but for cows fed fat, plasma cholesterol did not change with increasing dietary vitamin $\mathrm{E}$ (linear vitamin $\mathrm{E} \times$ fat supplementation contrast, $P<0.05$ ). In previous studies with cattle, vitamin $\mathrm{E}$ intake has not affected plasma cholesterol (Weiss et al., 1992; Weiss et al., 1994; Baldi et al., 2000 ) regardless of whether supplemental fat was fed. However, in those studies, periparturient cows were used and intake of $\alpha$-tocopherol was usually much lower than in the current study. The reduced form of glutathione inhibits 3-hydroxy-3-methylglutaryl CoA reductase (rate-limiting enzyme for cholesterol synthesis) in rats (Kim et al., 1992). Dairy cows fed 1000 IU/d of vitamin $\mathrm{E}$ had higher concentration of reduced glutathione compared with cows fed no supplemental vitamin E (Brzezinska-Slebodzinska et al., 1994). The large amounts of vitamin $\mathrm{E}$ fed in this study may have increased the concentration of reduced glutathione. For cows fed supplemental fat, the stimulatory effect of the fat on cholesterol synthesis may have overwhelmed any effect of vitamin E. Interactions between the linear effect of vitamin $\mathrm{E}$ and type of fat supplementation $(P<0.05)$ and quadratic effect of vitamin $\mathrm{E}$ $\times$ type of fat supplementation $(P<0.04)$ were observed. Those interactions were caused by the lower plasma cholesterol concentration for cows fed the RSB diet plus $125 \mathrm{IU} / \mathrm{kg}$ vitamin E treatment (Table 5).

\section{Plasma and Milk $\alpha$-Tocopherol}

Concentrations of $\alpha$-tocopherol in milk and plasma increased $(P<0.01)$ within $14 \mathrm{~d}$ of treatment and did not change $(P>0.60)$ from $\mathrm{d} 14$ to $\mathrm{d} 28$ of treatment
(Figure 1). When only d 14 and 28 were analyzed, day and the day by treatment interactions were not significant $(P>0.25)$. The data in Table 5 are averaged over $\mathrm{d} 14$ and 28 .

Concentrations of $\alpha$-tocopherol in plasma were higher $(P<0.01)$ for cows fed fat, and concentrations increased linearly $(P<0.001)$ with increasing dietary vitamin $\mathrm{E}$ (Table 5). However, the linear effect was influenced by fat supplementation (linear vitamin $\mathrm{E} \times$ fat supplementation contrast, $P<0.001$ ). Plasma $\alpha$ tocopherol increased more with increasing dietary vitamin $\mathrm{E}$ when fat was included in the diet than when supplemental fat was not fed (Table 5). Source of fat did not affect plasma $\alpha$-tocopherol concentrations. In previous experiments, feeding supplemental fat (Casoaps of fatty acids) to periparturient cows (Weiss et al., 1994) and early lactation cows (Atwal et al., 1990) increased plasma concentrations of $\alpha$-tocopherol. Baldi et al (2000), however reported no effect on plasma $\alpha$-tocopherol or cholesterol when Ca-soaps of fatty acids were fed to periparturient cows. The basal diet in that study probably had substantially more crude fat than the basal diet in the Weiss et al. (1994) study because it contained more concentrate (49 vs. $12 \%$ of the DM) and soybeans.

A quadratic vitamin $\mathrm{E} \times$ supplemental fat source interaction was observed for plasma $\alpha$-tocopherol $(P<$ 0.05). Cows fed tallow had higher plasma $\alpha$-tocopherol concentrations than cows fed RSB when fed the 125 IU/kg vitamin E treatment. The opposite was observed when the $250 \mathrm{IU} / \mathrm{kg}$ vitamin $\mathrm{E}$ treatment was fed. This interaction was likely the result of alterations in blood lipid concentrations. Plasma cholesterol can be used as an index of plasma lipid concentrations (Maynard et al., 1931; Herdt and Smith, 1996). Within vitamin E treatment, plasma cholesterol and $\alpha$-tocopherol were correlated $\left(\mathrm{r}^{2}=0.5\right.$ to 0.67$)$. When plasma $\alpha$-tocopherol was expressed relative to plasma cholesterol $(\mathrm{mg} \alpha$ tocopherol/g cholesterol), no fat treatment effects and no interactions between vitamin $\mathrm{E}$ treatments and fat treatments were observed $(P>0.25)$. The $\alpha$-tocopherol to cholesterol ratio increased linearly $(P<0.001)$ and quadratically $(P<0.02)$ with increasing dietary vita$\min \mathrm{E}$.

The concentration of $\alpha$-tocopherol in milk $(\mathrm{mg} / \mathrm{L})$ and milk fat $(\mathrm{mg} / \mathrm{kg})$ increased linearly $(P<0.001 ; P<0.03$, respectively) and quadratically $(P<0.01 ; P<0.06$, respectively) with increasing dietary vitamin $\mathrm{E}$ (Table 5 ). The concentrations of $\alpha$-tocopherol in milk or milk fat were not different $(P>0.20)$ between cows fed or not fed fat, which is consistent with most previous studies (Atwal et al., 1990; Atwal et al., 1991; Charmley and Nicholson, 1994; Weiss et al., 1994; Baldi et al., 2000). Focant et al (1998) reported that cows fed a 

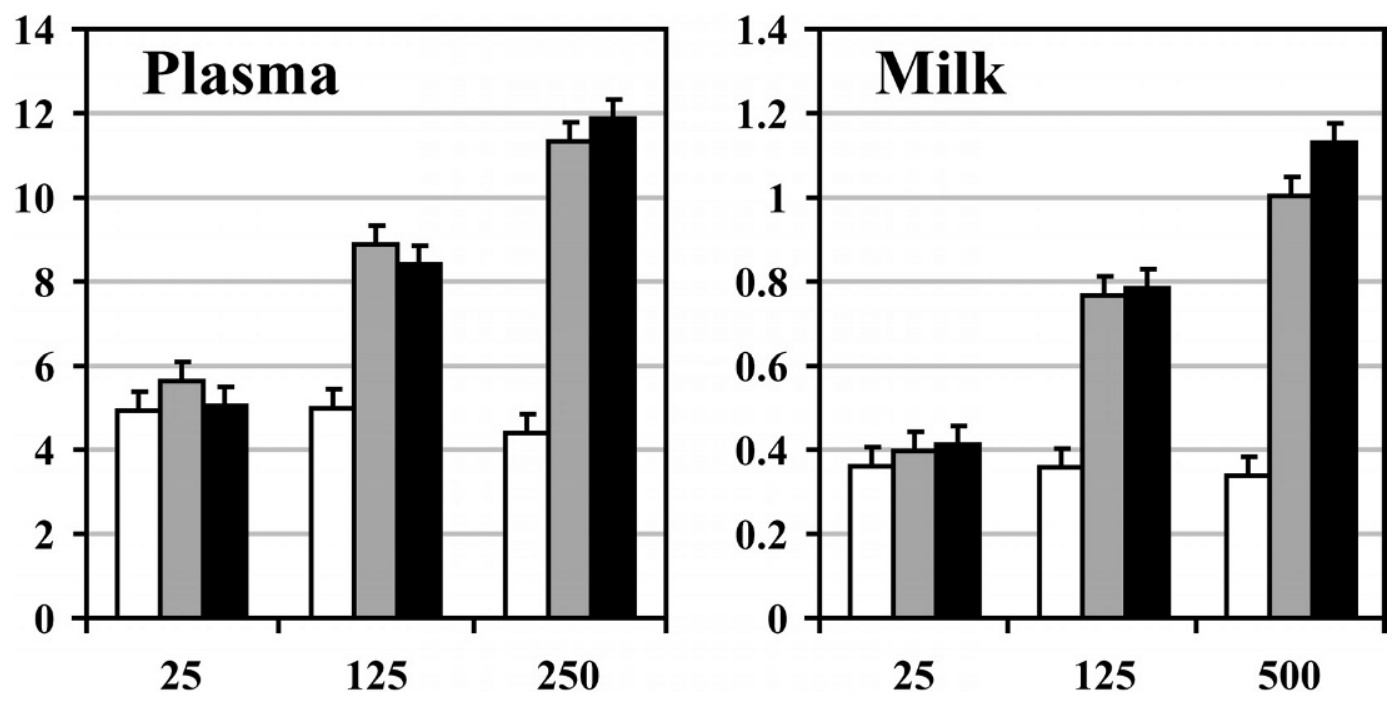

Figure 1. Concentrations of $\alpha$-tocopherol in plasma and milk (mg/L) for cows fed diets with 25, 125, or 250 IU of supplemental vitamin $\mathrm{E} / \mathrm{kg}$ of DM on d 0 (open bar), d 14 of supplementation (gray bar), or d 28 of supplementation (black bar). Data are averaged over fat treatments.

diet with a mixture of extruded linseeds and rapeseeds had higher concentration of $\alpha$-tocopherol in milk than cows not fed supplemental fat. In that experiment, concentrations and secretion rate of $\alpha$-tocopherol in milk were about two times higher than values reported in most other studies and transfer of dietary $\alpha$-tocopherol to milk for cows not fed supplemental vitamin $\mathrm{E}$ was about three times higher than values reported elsewhere. In the present study, the concentration of $\alpha$-tocopherol per liter of milk, but not per gram of milk fat, was higher $(P<0.05)$ for cows fed RSB than for those fed tallow. In previous experiments, cows fed full-fat soybeans had higher concentrations of $\alpha$-tocopherol in milk ( $\mathrm{mg} / \mathrm{L}$ and $\mathrm{mg} / \mathrm{kg}$ fat) compared with cows fed tallow (Morales et al., 2000) or Ca-soaps of fatty acids (Charmley and Nicholson, 1994). In those studies, intake of $\alpha$-tocopherol was probably similar (based on DMI) among treatments. In the present experiment, differences in intake of $\alpha$-tocopherol between cows fed RSB and tallow likely was the predominant cause for higher milk $\alpha$-tocopherol. Because cows fed tallow had lower concentrations of milk fat than cows fed RSB, $\alpha$-tocopherol per unit of milk fat was not different for cows fed tallow or RSB. The significant linear vitamin $\mathrm{E} \times$ source of supplemental fat interaction for $\alpha$-tocopherol ( $\mathrm{mg} / \mathrm{kg}$ of milk fat) appeared to be caused mostly by variation in milk fat among vitamin E treatments.

The amount of $\alpha$-tocopherol secreted each day into milk increased linearly $(P<0.001)$ and quadratically

Table 5. Effect of dietary fat and vitamin E (25, 125, or $250 \mathrm{IU} / \mathrm{kg}$ DM) on concentrations of $\alpha$-tocopherol ( $\alpha$-Toc) in milk and plasma (data are average of $d 14$ and 28 observations).

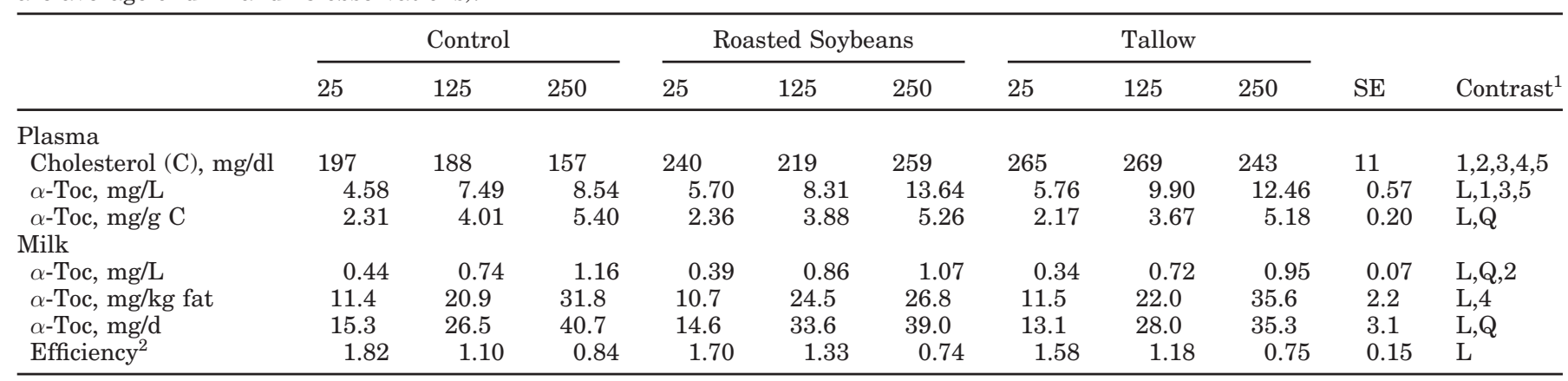

${ }^{1}$ Contrasts $(P<0.05)$ : L = linear effect of vitamin E treatment; $\mathrm{Q}=$ quadratic effect of vitamin $\mathrm{E} ; 1$ = fat-supplemented vs. control; 2 = roasted soybeans $(\mathrm{RSB})$ vs. tallow; $3=$ interaction between linear effect of vitamin $\mathrm{E}$ and fat vs. no fat; $4=$ interaction between linear effect of vitamin $\mathrm{E}$ and RSB vs. tallow; 5 = interaction between quadratic effect of vitamin $\mathrm{E}$ and RSB vs. tallow.

${ }^{2}$ Efficiency $=\alpha$-Tocopherol secreted in milk $(\mathrm{mg} / \mathrm{d})$ divided by $\alpha$-tocopherol intake $(\mathrm{mg} / \mathrm{d}) \times 100$. 
Table 6. Regression equations for relationships of intake $(\mathrm{mg} / \mathrm{d})$ of $\alpha$-tocopherol ( $\alpha$-Toc) and $\alpha$-Toc in milk and plasma $(\mathrm{N}=54 \text { except where noted })^{1}$.

\begin{tabular}{llllllll}
\hline Dependent variable & $\mathrm{b}_{0}$ & $\mathrm{SE}\left(\mathrm{b}_{0}\right)$ & $\mathrm{b}_{1}$ & $\mathrm{SE}\left(\mathrm{b}_{1}\right)$ & $\mathrm{b}_{2}$ & $\mathrm{SE}\left(\mathrm{b}_{2}\right)$ & ERST \\
\hline Plasma $\alpha$-Toc, mg/L & & & & & & & \\
Cows not fed fat $(\mathrm{N}=18)$ & $4.55^{2}$ & 0.47 & $0.90^{\mathrm{a}}$ & 0.16 & $\mathrm{NS}$ & $\ldots$ & 1.73 \\
Cows fed fat $(\mathrm{N}=36)$ & $4.55^{2}$ & 0.47 & $1.71^{\mathrm{b}}$ & 0.14 & $\mathrm{NS}$ & $\ldots$ & 1.73 \\
Plasma $\alpha$-Toc, mg/g cholesterol & $1.25^{2}$ & 0.24 & 1.33 & 0.18 & -0.100 & 0.028 & 0.49 \\
Milk $\alpha$-Toc, mg/L & 0.11 & 0.09 & 0.36 & 0.07 & -0.033 & 0.011 & 0.20 \\
Milk $\alpha$-Toc, mg/kg milk fat & 1.41 & 2.97 & 12.26 & 2.42 & -1.25 & 0.38 & 6.69 \\
Milk $\alpha$-Toc, mg/d & 3.59 & 3.56 & 13.49 & 2.86 & -1.25 & 0.45 & 7.89 \\
\hline
\end{tabular}

${ }^{1} \mathrm{~b}_{0}=$ intercept; $\mathrm{b}_{1}=$ linear term; $\mathrm{b}_{2}=$ quadratic term; ERSE = estimated residual standard error; NS $=P$ $>0.10$.

${ }^{2}$ Intercept different from $0(P<0.01)$.

${ }^{\mathrm{a}, \mathrm{b}}$ Slopes differ between cows fed supplemental fat and those not fed fat $(P<0.05)$.

$(P<0.02)$ with increasing dietary vitamin E. Cows fed RSB tended $(P<0.12)$ to secrete more $\alpha$-tocopherol in milk than cows fed tallow. The ratio of $\alpha$-tocopherol to polyunsaturated fatty acids (PUFA) in milk may be important for oxidative stability of the milk. On a daily basis, cows fed RSB secreted 274 mmols of PUFA in their milk, compared with 149 and $122 \mathrm{mmol}$ for cows fed no supplemental fat or tallow, respectively. The difference in amount of PUFA secreted per day among treatments was much greater than the difference in amount of $\alpha$-tocopherol secreted per day. Milk from cows fed RSB with 25,125 or $250 \mathrm{IU}$ vitamin $\mathrm{E} / \mathrm{kg}$ DM treatments contained $0.13,0.29$, and 0.32 mmols of $\alpha$-tocopherol/mole of PUFA, respectively. The ratio was much higher for cows fed tallow $(0.23,0.48$, and 0.84 for 25,125 , and $250 \mathrm{IU} / \mathrm{kg}$ treatments) or no supplemental fat $(0.22,0.45$, and 0.62 , respectively). The adequate ratio (if any) of $\alpha$-tocopherol to PUFA is not known. Milk with $0.21 \mathrm{mmol} \alpha$-tocopherol $/ \mathrm{mol}$ PUFA developed oxidized flavor after $48 \mathrm{~h}$ of storage, but milk with a ratio of 0.38 did not (Charmley and Nicholson, 1994).

\section{Relationships with $\alpha$-Tocopherol Intake}

Intake of total $\alpha$-tocopherol ranged from about 650 $\mathrm{mg} / \mathrm{d}$ to $6050 \mathrm{mg} / \mathrm{d}$. The concentration of $\alpha$-tocopherol in plasma increased linearly with increasing intake of vitamin $\mathrm{E}$ but the slope was almost two times higher $(P<0.01)$ for cows fed fat than for those not fed fat (Table 6; Figure 2). Supplemental fat did not affect the intercept but the intercept was greater than $0(P$ $<0.01$ ). When plasma $\alpha$-tocopherol was expressed per unit of plasma cholesterol a single equation fit the data (i.e, no effect of fat treatment), but the relationship was quadratic (Table 6). The calculated maximum concentration was $5.7 \mathrm{mg} \alpha$-tocopherol/g cholesterol, which would occur at an intake of about $6400 \mathrm{mg}$ of $\alpha$-tocopherol/d. All measures of milk $\alpha$-tocopherol (mg/
$\mathrm{L}, \mathrm{mg} / \mathrm{kg}$ of milk fat, and $\mathrm{mg} / \mathrm{d}$ ) had quadratic relationships with $\alpha$-tocopherol intake and were not influenced by fat treatment (Table 6). Calculated maximum concentrations of $\alpha$-tocopherol in milk were $1.1 \mathrm{mg} / \mathrm{L}$ and $31 \mathrm{mg} / \mathrm{kg}$ milk fat, and the calculated maximum secre-
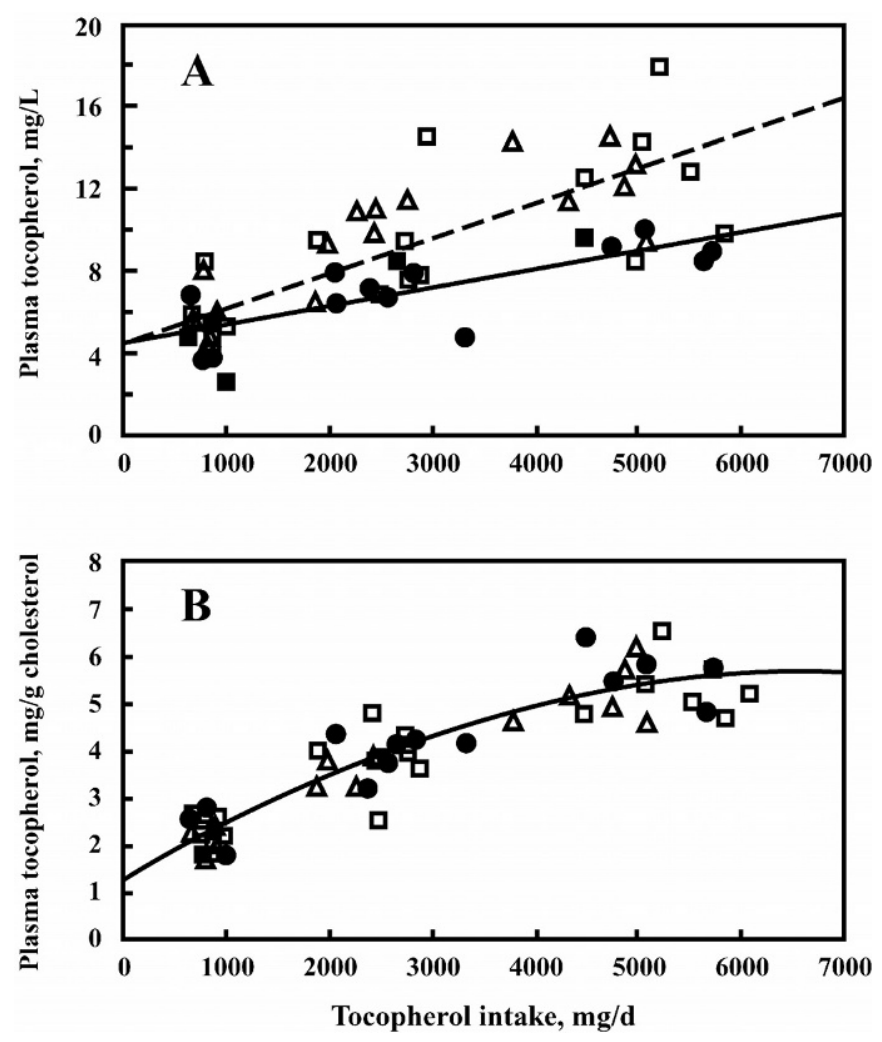

Figure 2. Relationship between $\alpha$-tocopherol intake and concentration in plasma (Panel A). The slope was greater $(P<0.05)$ for cows fed fat (dashed line) than for cows not fed fat (solid line) (Table 6). The relationship between $\alpha$-tocopherol intake and plasma concentration relative to plasma cholesterol (Panel B). Fat treatment did not affect the relationship (Table 6). Circles = no supplemental fat, squares = roasted soybeans, and triangles $=$ tallow. Each point represents a cow $(\mathrm{N}=54)$. 
tion of $\alpha$-tocopherol was $40 \mathrm{mg} / \mathrm{d}$. These calculated maxima occurred at intakes between 4900 to $5400 \mathrm{mg}$ $\alpha$-tocopherol/d.

Gross efficiency (output of milk $\alpha$-tocopherol/intake of $\alpha$-tocopherol) decreased with increasing vitamin $\mathrm{E}$ intake but was not affected by fat supplementation (Table 5). At the lowest intake of $\alpha$-tocopherol, gross efficiency was $1.7 \%$ of intake, and at the highest $\alpha$ tocopherol intake it was $0.78 \%$. The decreasing transfer efficiency with increasing dietary vitamin $\mathrm{E}$ has at least three explanations. One possible reason for differences in gross transfer efficiency between cows fed high and low amount of $\alpha$-tocopherol is the form of the vitamin E. About $42 \%$ of the $\alpha$-tocopherol consumed by cows fed the $25 \mathrm{IU} / \mathrm{kg}$ diets were from basal ingredients $(R R R$ - $\alpha$-tocopherol) compared with $7 \%$ for cows fed the $250 \mathrm{IU} / \mathrm{kg}$ diets (the remaining $\alpha$-tocopherol was from all-rac $\alpha$-tocopheryl acetate). Gut absorption and distribution within tissues may differ between isomers. Another possible reason is that absorption from the gut or carrying capacity in the plasma of $\alpha$-tocopherol is limited and becomes saturated at high vitamin $\mathrm{E}$ intakes. A third reason is that the biological capacity of mammary cells to secrete $\alpha$-tocopherol in milk is limited (Jensen et al., 1999).

\section{Relationships Between Plasma and Milk $\alpha$-tocopherol}

Milk $\alpha$-tocopherol (mg/L, $\mathrm{mg} / \mathrm{kg}$ of milk fat, and $\mathrm{mg} /$ d) was related linearly (quadratic terms were not significant; $P>0.10$ ) with concentrations of $\alpha$-tocopherol in plasma, but fat supplementation (supplemented vs. control) influenced $(P<0.05)$ the relationships (Figure 3 ). The change in milk $\alpha$-tocopherol ( $\mathrm{mg} / \mathrm{L}, \mathrm{mg} / \mathrm{kg}$ of milk fat, and $\mathrm{mg} / \mathrm{d}$ ) per unit change in plasma $\alpha$-tocopherol $(\mathrm{mg} / \mathrm{L})$ was 30 to $50 \%$ greater for cows not fed fat than for cows fed fat (Table 7). Milk $\alpha$-tocopherol also was related linearly (quadratic terms not significant; $P>0.10$ ) with concentrations of $\alpha$-tocopherol in plasma expressed relative to plasma cholesterol, but in this case, fat treatment did not influence $(P>$ 0.25) the relationships (Table 7).

Jensen et al (1999) used Michaelis-Menten kinetics to describe the relationship between concentrations of $\alpha$-tocopherol in plasma (i.e., substrate) and daily secretion of $\alpha$-tocopherol in milk (i.e., velocity) and concluded that the mammary gland has a maximal capacity for secreting $\alpha$-tocopherol (about $36 \mathrm{mg} / \mathrm{d}$ ) and was affected by genetics. However, the linear relationship between $\alpha$-tocopherol concentrations in plasma and daily secretion of $\alpha$-tocopherol in milk that we observed suggests that the capacity to transfer $\alpha$-tocopherol from plasma to milk was not a limiting factor.
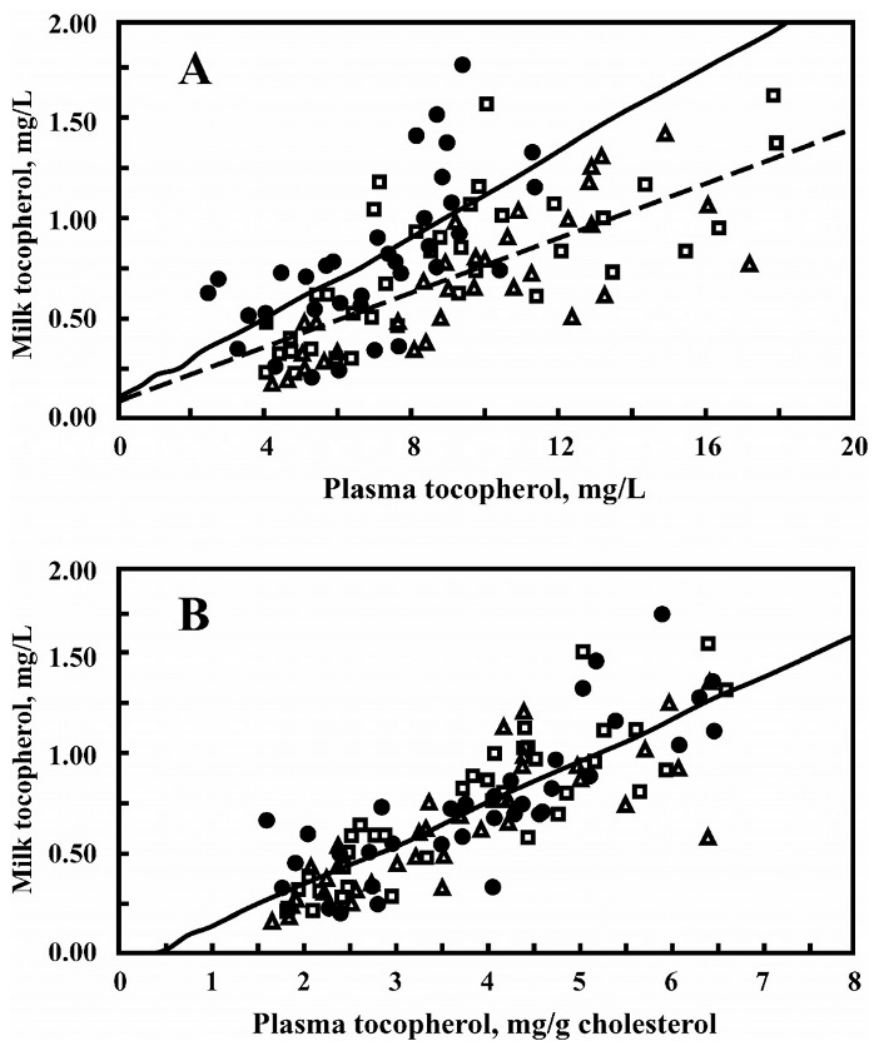

Figure 3. Relationship between concentrations of $\alpha$-tocopherol in milk and plasma (Panel A). The slope was greater $(P<0.05)$ for cows not fed fat (solid line) than for cows fed fat (dashed line) (Table 6). The relationship between concentration of $\alpha$-tocopherol in milk and in plasma expressed relative to plasma cholesterol (Panel B). Fat treatment did not affect the relationship. Circles $=$ no supplemental fat, squares $=$ roasted soybeans and triangles $=$ tallow. Each point represents a single cow at either d 14 or d $28(\mathrm{~N}=54$ cows, 108 observations).

Various linear expressions of Michaelis-Menten kinetics (i.e., Hanes plot and Lineweaver-Burke plot) either did not fit our data or produced nonsensical parameters such as a negative Vmax (data not shown). However, when intake was used to express substrate and either plasma concentration ( $\mathrm{mg} / \mathrm{g}$ cholesterol) or secretion of $\alpha$-tocopherol in milk (mg/d) was velocity, Michaelis-Menten kinetics fit the data (data not shown). Dietary fat supplementation affected plasma concentrations of $\alpha$-tocopherol expressed per liter but did not affect plasma concentration per unit of cholesterol or any measure of milk $\alpha$-tocopherol. These data in total suggests that uptake of $\alpha$-tocopherol by the mammary gland is a function of concentration of $\alpha$ tocopherol in the plasma lipid fraction (i.e., capacity of the plasma lipoproteins to carry $\alpha$-tocopherol) and that enrichment of that fraction with $\alpha$-tocopherol is limited (Vmax from Lineweaver-Burk regression $=6.3$; 
Table 7. Regression equations for relationships between plasma and milk $\alpha$-tocopherol ( $\alpha$-toc $)^{1}$.

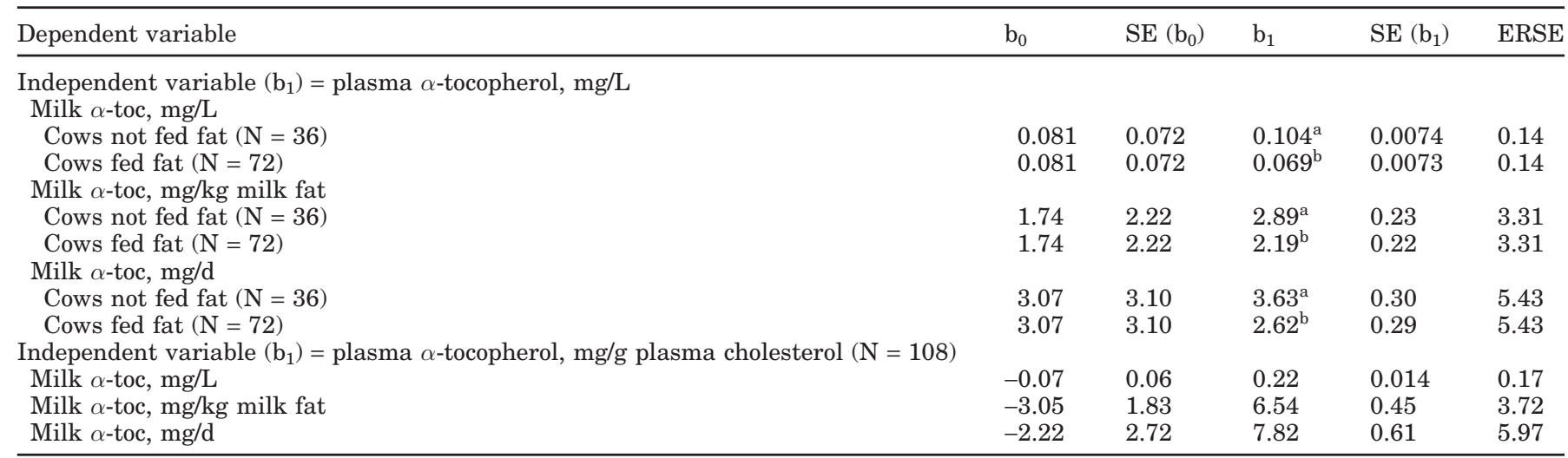

${ }^{\mathrm{a}, \mathrm{b}}$ Coefficients within a dependent variable differ $(P<0.05)$.

${ }^{1} \mathrm{~b}_{0}=$ intercept (all intercepts were not different from $0 ; P>0.15$ ); $\mathrm{b}_{1}=$ linear term; ERSE = estimated residual standard error.

quadratic maximum $=5.7 \mathrm{mg} \alpha$-tocopherol/g cholesterol) by some factor.

\section{CONCLUSIONS}

Supplemental dietary fat increased concentrations of $\alpha$-tocopherol in plasma but did not affect milk $\alpha$ tocopherol. When plasma $\alpha$-tocopherol was expressed per gram of plasma cholesterol, no differences in the relationships between $\alpha$-tocopherol intake and plasma $\alpha$-tocopherol and between plasma and milk $\alpha$-tocopherol were observed between fat treatments. Maximum concentration and daily secretion rate of $\alpha$-tocopherol in milk occurred at a daily intake of approximately $5000 \mathrm{mg}$ of $\alpha$-tocopherol. Our data suggests that either the capacity to absorb $\alpha$-tocopherol from the gut or plasma carrying capacity limits the secretion rate of $\alpha$-tocopherol into milk. The calculated maxima occurred at the high end of the range of $\alpha$-tocopherol intakes used, therefore, studies with higher $\alpha$-tocopherol intakes are needed to verify this conclusion.

\section{REFERENCES}

Association of Official Analytical Chemists. 1990. Official Methods of Analysis. Vol. 1 15th ed. AOAC, Arlington, VA.

Atwal, A. S., M. Hidiroglou, and J. K. Kramer. 1991. Effects of feeding Protec and $\alpha$-tocopherol on fatty acid composition and oxidative stability of cow's milk. J. Dairy Sci. 74:140-145.

Atwal, A. S., M. Hidiroglou, J. K. G. Kramer, and M. R. Binns. 1990. Effects of feeding $\alpha$-tocopherol and calcium salts of fatty acids on vitamin $\mathrm{E}$ and fatty acid composition of cow's milk. J. Dairy Sci. 73:2832-2841.

Baldi, A., G. Savoini, L. Pinotti, E. Monfardini, F. Cheli, and V. Dell'Orto. 2000. Effects of vitamin E and different energy sources on vitamin $\mathrm{E}$ status, milk quality and reproduction in transition cows. J. Vet. Med. Ser. A 47:599-608.

Brzezinska-Slebodzinska, E., J. K. Miller, I. J.D. Quigley, J. R. Moore, and F. C. Madsen. 1994. Antioxidant status of dairy cows supplemented prepartum with vitamin E and selenium. J. Dairy Sci. 77:3087-3095.
Charmley, E., J. W. Nicholson, and J. A. Zee. 1993. Effect of supplemental vitamin $\mathrm{E}$ and selenium in the diet on vitamin $\mathrm{E}$ and selenium levels and control oxidized flavor in milk from Holstein cows. Can. J. Anim. Sci. 73:453-457.

Charmley, E., and J. W. G. Nicholson. 1994. Influence of dietary fat source on oxidative stability and fatty acid composition of milk from cows receiving a low or high level of dietary vitamin $\mathrm{E}$. Can. J. Anim. Sci. 74:657-664.

Focant, M., E. Mignolet, M. Marique, F. Clabots, T. Breyne, D. Dalemans, and Y. Larondelle. 1998. The effect of vitamin E supplementation of cow diets containing rapeseed and linseed on the prevention of milk fat oxidation. J. Dairy Sci. 81:1095-1101.

Food and Nutrition Board. 2000. Dietary Reference Intakes for Vitamin C, Vitamin E, Selenium, and Carotenoids. Natl. Acad. Press, Washington, DC.

Goering, H. K., C. H. Gordon, T. R. Wrenn, J. Bitman, R. L. King, and F. W. Douglas Jr. 1976. Effect of feeding protected safflower oil on yield, composition, flavor, and oxidative stability of milk. J. Dairy Sci. 59:416-425.

Grummer, R. R., and D. J. Carroll. 1991. Effects of dietary fat on metabolic disorders and reproductive performance of dairy cattle. J. Anim. Sci. 69:3838-3852.

Herdt, T. H., and J. C. Smith. 1996. Blood-lipid and lactation-stage factors affecting serum vitamin $\mathrm{E}$ concentrations and vitamin $\mathrm{E}$ cholesterol ratios in dairy cows. J. Vet. Diagn. Invest. 8:228-232.

Hogan, J. S., K. L. Smith, W. P. Weiss, D. A. Todhunter, and W. L. Shockey. 1990. Relationships among vitamin E, selenium, and bovine blood neutrophils. J. Dairy Sci. 73:2372-2378.

Indyk, H. E. 1988. Simplified saponification procedure for the routine determination of total vitamin $\mathrm{E}$ in dairy products, foods, and tissues by high-performance liquid chromatography. Analyst 113:1217-1221.

Jensen, S. K., A. K. B. Johannsen, and J. E. Hermansen. 1999. Quantitative secretion and maximal secretion capacity of retinol, beta-carotene and alpha-tocopherol into cows' milk. J. Dairy Res. 66:511-522.

Kim, S. H., P. Y. Chan, and G. D. Allen. 1992. Inhibition of elevated hepatic glutathione abolishes copper deficiency cholesterolemia. FASEB J. 6:2467-2471.

Kramer, J.K.G., V. Fellner, M.E.R. Dugan, F. D. Sauer, M. M. Mossoba, and M. P. Yurawecz. 1997. Evaluating acid and base catalysts in the methylation of milk and rumen fatty acids with special emphasis on conjugated dienes and total transfatty acids. Lipids 32:1219-1228.

Maynard, L. A., E. S. Harrison, and C. M. McCay. 1931. The changes in the total fatty acids, phospholipid fatty acids and cholesterol of the blood during the lactation cycle. J. Biol. Chem. 92:263-270.

Morales, M. S., D. L. Palmquist, and W. P. Weiss. 2000. Milk fat composition of Holstein and Jersey cows with control or depleted 
copper status and fed whole soybeans or tallow. J. Dairy Sci. 83:2112-2119.

National Research Council. 1989. Nutrient Requirements for Dairy Cattle. Natl. Acad. Sci, Washington DC.

Onetti, S. G., R. D. Shaver, M. A. McGuire, and R. R. Grummer. 2001. Effect of type and level of dietary fat on rumen fermentation and performance of dairy cows fed corn silage-based diets. J. Dairy Sci. 84:2751-2759.

SAS/STAT User's Guide: Statistics. 1999. Version 8 Edition. SAS Institute Inc., Cary, NC. SIGMA. 1999. Cholesterol. Proc. 402. Sigma Diagnostics, St. Louis, MO.

Sukhija, P. S., and D. L. Palmquist. 1988. Rapid method for determination of total fatty acid content and composition of feedstuffs and feces. J. Agric. Food Chem. 36:1202-1206.

St.-Laurent, A. M., M. Hidiroglou, M. Snoddon, and J. W. Nicholson. 1990. Effect of $\alpha$-tocopherol supplementation to dairy cows on milk and plasma $\alpha$-tocopherol concentrations and on spontaneous oxidized flavor in milk. Can. J. Anim. Sci. 70:561-570.
Timmons, J. S., W. P. Weiss, D. L. Palmquist, and W. J. Harper. 2001. Relationships among dietary roasted soybeans, milk components, and spontaneous oxidized flavor of milk. J. Dairy Sci. 84:2440-2449.

Tyrrell, H. F., and J. T. Reid. 1965. Prediction of the energy value of cow's milk. J. Dairy Sci. 48:1215-1223.

Van Soest, P. J., J. B. Robertson, and B. A. Lewis. 1991. Methods for dietary fiber, neutral detergent fiber, and nonstarch polysaccharides in relation to animal nutrition. J. Dairy Sci. 74:3583-3597.

Weiss, W. P., R. R. Grummer, and S. G. Onetti. 2003. Statistical relationships between milk fatty acid profile and milk fat percentage. J. Dairy Sci. (submitted).

Weiss, W. P., J. S. Hogan, K. L. Smith, D. A. Todhunter, and S. N. Williams. 1992. Effect of supplementing periparturient cows with vitamin E on distribution of $\alpha$-tocopherol in blood. J. Dairy Sci. 75:3479-3485.

Weiss, W. P., J. S. Hogan, K. L. Smith, and S. N. Williams. 1994. Effect of dietary fat and vitamin $\mathrm{E}$ on $\alpha$-tocopherol and $\beta$-carotene in blood of peripartum cows. J. Dairy Sci. 77:1422-1429. 